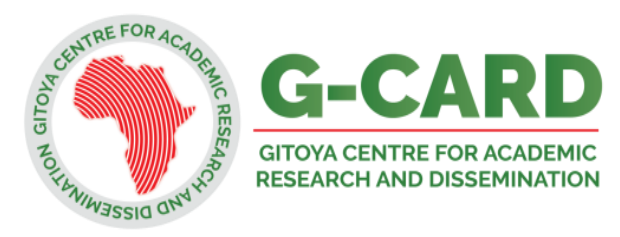

East African Journal of Education and Social Sciences

EAJESS April-May 2021, Vol. 2, No. 2, pp. 127-135

ISSN: 2714-2132 (Online), 2714-2183 (Print), Copyright @ The Author(s)

Published by G-Card

DOI: https://doi.org/10.46606/eajess2021v02i02.0083

URL: http://eajess.ac.tz

\title{
Fostering Entrepreneurial Intentions among University Students in Ghana: Proposing a Conceptual Framework
}

\author{
Stephen Arthur, $\mathrm{PhD}^{1}$, Josephine Ganu, $\mathrm{PhD}^{2 *}$ and Abdulai Issaka ${ }^{1}$ \\ ${ }^{1}$ Valley View University, Ghana \\ ${ }^{2}$ Adventist University of Africa, Kenya \\ *Corresponding Mail: ganuj@aua.ac.ke
}

\begin{abstract}
The positive effect of students' exposure to entrepreneurship education and entrepreneurship intention is well established in extant literature. Ghana is an example of an emerging country that has embraced entrepreneurship and entrepreneurial education to curb unemployment levels, especially among university graduates. However, countless university graduates especially in Ghana prefer seeking non-existent jobs rather than establishing their businesses. Therefore, this paper proposes a conceptual framework that highlights entrepreneurial competencies, social support, and business opportunities as essential factors that can potentially enhance the entrepreneurial intentions of university students, particularly fresh graduates. Specifically, we offer three propositions with the anticipation of generating fresh research interest for future studies in entrepreneurial intentions among university graduates. Understanding these driving forces leading to entrepreneurial intentions among young graduates is critical for effective entrepreneurship education and self-employment in Ghana and beyond.
\end{abstract}

Keywords: Entrepreneurial intentions, entrepreneurship education, social support, business opportunities, entrepreneurial competencies

\section{Introduction}

One of the Sustainable Development Goals is to promote inclusive and sustainable economic growth, full and productive employment and decent work for all (United Nations, n.d.). However, youth unemployment and underemployment remain a global challenge, particularly in Africa (African Development Report, 2016). According to the African Development Report (2017), approximately eleven million graduates enter the job market in Africa every year. At the same time, only about three million new jobs are created on the continent, creating an annual estimated jobs gap of about eight million. As a result, the labor markets are overwhelmed with the excess labor supply.

Entrepreneurship seems to be a promising alternative option for bridging the gap between labor demand and supply. Therefore, it is not surprising to see governments worldwide showing great interest in the potential of entrepreneurial ventures. Utami (2017) suggests the need to aggressively promote the entrepreneurial spirit among individuals, especially university students, to reduce unemployment and poverty. According to Neck, Neck and Murray (2021), entrepreneurship is a way of thinking, acting, and being that combines the ability to find or create new opportunities with the courage to act on them. Entrepreneurship education has the potential to equip students with entrepreneurial mindset and skills that support the creation of new business opportunities and ventures (Robb, Valerio \& Parton, 2014; Adelaja \& Minai, 2018; Jwara \& Hoque, 2018). This suggests a necessity for institutions of higher learning to inspire and stimulate intellectual curiosity and encourage entrepreneurial career choices in students. As prospective entrepreneurs, students need the entrepreneurial training that enhances their development and demonstration of entrepreneurial competencies. Such orientation will provide students with a set of skills that empowers them to create opportunities and control their personal goals and ambitions. 
The positive effect of students' exposure to entrepreneurship education and entrepreneurship intention is well established in extant literature (Adelaja \& Minai, 2018; Ching \& Kitahara, 2017). However, despite the several efforts to integrate entrepreneurial education in universities in Ghana, the expected results have not been achieved. This is revealed by the fact that job seeking and unemployment levels among university graduates remain high (Amanamah, Acheampong, \& Owusu, 2018). As such, the economy of Ghana has been characterized by protracted unemployment of the majority of the people (Robb, Valerio \& Parton, 2014; Ananga, Adzahlie-Mensah, \& Tamanja, 2016), leading to the formation of the 'Unemployed Graduates Association of Ghana' (Bosompem, Dadzie \& Tandoh, 2017). According to Aryeetey (2001), it is estimated that approximately 50 percent of university and polytechnic graduates in Ghana will not find jobs for two years after their national service, and 20 percent will not find jobs for three years. Therefore, intentional entrepreneurship education and sensitization in universities are critical for mitigating the unemployment situation in Ghana.

More so, countless university graduates especially in Ghana, prefer seeking non-existent jobs rather than establishing their businesses (Denanyoh, Adjei, \& Danso, 2018). It is unclear why many university graduates, particularly in Ghana perceive selfemployment as the last career option. Therefore, this paper sought to explore the role of entrepreneurial competencies, social support and business opportunities in shaping the entrepreneurial intentions of university students, particularly fresh graduates. Understanding these driving forces leading to entrepreneurial intentions among young graduates is critical for effective entrepreneurship education and self-employment in Ghana and beyond. Therefore, this paper proposes a conceptual framework suggesting three significant factors that could translate entrepreneurial intentions into positive actions. The rest of the paper highlights the theoretical underpinning of entrepreneurial intentions, presents the discussion of the conceptual framework and the corresponding propositions, and then gives the conclusions.

\section{Theoretical Framework}

The theoretical foundation of this paper is rooted in Ajzen's theory of planned behavior (Ajzen 1991) and Shapero's Model of Entrepreneurial Event (1982). The theory of planned behavior suggests that behavioral intentions are a function of individual attitudes toward the behavior, a subjective norm, and a perceived behavior control (Ajzen, 1991). Individual attitudes are a person's overall evaluation of whether performing the behavior is good or bad (Ajzen, 1991). By implication, a university student who believes that becoming an entrepreneur will lead to positive results will hold a positive attitude toward entrepreneurship. By contrast, a student who thinks that becoming an entrepreneur means failure will have an unfavorable attitude toward venturing into entrepreneurship.

The subjective norm in the theory of planned behavior is a person's belief that people of importance, such as family, will endorse or object an intended behavior (Ham, Jeger \& Ivković, 2015; Ajzen, 1991). For instance, a young university graduate considering starting a business may consider what their parents think of the idea to start a business. If the parents are against the idea, the young person will feel social pressure to avoid acting on the intention. Subjective norm is also influenced by the person's motivation to comply with the most important people. Lastly, perceived behavioral control is an individual's evaluation of the likelihood of successfully performing the intended behavior (Ajzen, 1991). Thus, the perceived behavioral control describes a person's level of self-efficacy and the corresponding perceptions of the ease or difficulty of starting a new business venture.

Similarly, Shapero (1982) posited that entrepreneurial intentions are influenced by perceived desirability, perceived feasibility and a propensity to take action. Perception of desirability is the extent to which a young graduate desires starting a new business because it is attractive. Perception of feasibility is the degree to which the young graduate thinks that he or she is capable of starting a new business. One must believe that starting a business is both desirable and feasible before entrepreneurial intentions are acted upon (Shapero, 1982; Ranga, 2019).

\section{Conceptual Framework}

The intention to undertake a specific behavior, such as beginning a new business venture, is influenced by several personal and contextual factors. Context is the circumstances or conditions that shape the decision to consider entrepreneurship as a career choice (Greene, 2020). The context an individual is exposed to provides situational opportunities and constraints to start and run a venture (Tognazzo, 
Gianecchini \& Gubitta, 2017). In this case, for newly minted university graduates, the potency of entrepreneurial intentions rests on critical factors as proposed in Figure 1. Thus, students' willingness to start a new venture as a career option is mainly influenced by their level of competence, the extent of social support and the business opportunities available. Besides, personal qualities such as determination, courage, persistence, curiosity, confidence and optimism are essential. Therefore, we postulate that these factors determine the attitude of young graduates about their intention to opt for entrepreneurship as a career choice. We further discuss each of these factors and how they influence entrepreneurial intentions.

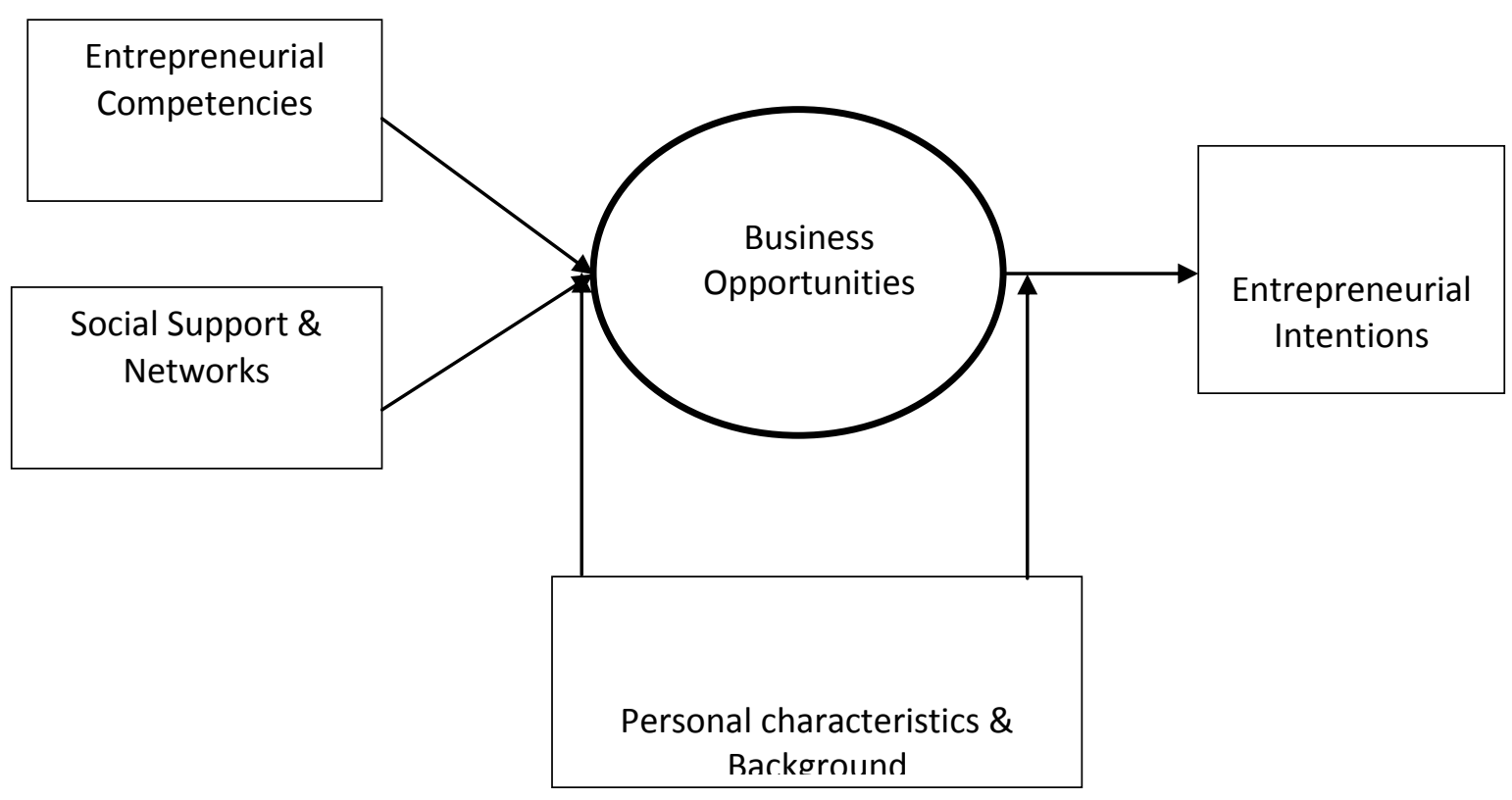

Figure1: Conceptual Framework

\section{Entrepreneurial Competencies and Intentions}

Entrepreneurship is a deliberate behavior and therefore entrepreneurial intentions are the foundation of the desire to start a new business. Generally, an intention is defined as the degree to which a person resolves to act in a certain way (Morwitz \& Munz 2021). By extension, an entrepreneurial intention is a strong determination to set up a new business venture and willfully plan to do so at some point in the future (Al-Jubari, Hassan \& Liñán, 2019). Thus, a person with entrepreneurial intentions commits to a particular behavior that motivates the person to act on his/her innovative ideas to start a business. Generally, the stronger the intentions, the more likely they are to predict the intended behavior.

Given the critical role of entrepreneurial intent as a predictor of entrepreneurial behavior, scholars suggest two dominant dimensions - goal and implementation intention. The intention to start a business is a plan of a specific goal while the intention to start a business in the near future is a plan of implementation (Esfandiar, Sharifi, Pratt \&
Altinay, 2019). The point of divergence is the time frame an individual assigns to the launch of the business. Those with the implementation intention may have a specific time in mind. In contrast, those with goal intention may express a mere desire, will, aspiration and interest to opt for self-employment as a career option but without specific timelines. A young graduate's perceived level of entrepreneurial competencies can influence his/her entrepreneurial self-efficacy and subsequent well-meaning intentions.

Generally, while students may have little experience, the university context is a crucial element that affects their entrepreneurial inclination. Therefore, the ability to learn the art of entrepreneurship by acquiring relevant knowledge, skills, abilities and other characteristics (KSAOs) is key to building entrepreneurial competencies and entrepreneurial intentions to start and run a successful business or a career. According to Lackéus (2015), the goal of entrepreneurial education is to develop entrepreneurial competencies. A university graduate is competent if 
he or she has the knowledge, skills and attitudes needed to create value for the marketplace.

Knowledge can be described as the "know-how, know-what, know-where, know-when, and knowwhy" for making sense of information (de Wit, 2017, p. 189). Examples of knowledge that university students can acquire are market insights, understanding of the business environments, how to get things done with little resources, risk management, etc. Having relevant knowledge is an important tool for establishing a business, improving organizational efficiency and strengthening the company's competitive advantage (Salunke, Weerawardena, \& McColl-Kennedy, 2019). On the other hand, entrepreneurial skills are the ability to effectively develop and manage a business (Mamabolo, Kerrin \& Kele, 2017). Examples of entrepreneurial skills include creativity, interpersonal skills, strategic skills and opportunity recognition. The significance of attitude in building entrepreneurial competencies cannot be minimized. A student can acquire all the valuable knowledge and skills but intentions cannot be acted upon without a positive attitude. Lackéus (2015) enumerates perseverance, self-efficacy, innovativeness, proactiveness and passion as examples of a positive attitude.

Thus, entrepreneurial competencies and characteristics such as opportunity recognition, riskbearing, initiative-taking, problem-solving, perseverance, market awareness, creativity, conceptual thinking, etc., enable young graduates to successfully identify and pursue new business opportunities (Markowska, 2011). These competencies can be developed through pedagogic research, students' education and educational programs (Ustyuzhina, Mikhaylova, \& Abdimomynova, 2019). The ability to combine knowledge, skills and other abilities as resources is the embodiment of entrepreneurial competencies (Al-Mamun, Nawi, and Zainol, 2016).

Entrepreneurship education can therefore enhance students' knowledge, skills and attitude toward a positive entrepreneurial intention. However, just having an entrepreneurship course in the curriculum may not be enough. To enhance the quality of entrepreneurial education, university educators have to reconsider their teaching approaches and use more experiential teaching methods and techniques to engage and challenge students (Dabić \& Pietrzykowski, 2011). For example, Rebernik and Širec (2011) argue that students are often expected to start their business ventures only after graduating. Such a situation can be likened to students in a teacher education program who never had the opportunity to apply their pedagogical knowledge and skills in practice before their graduation. Therefore, the goal of entrepreneurship educators is to deliberately train students to think and learn valuable skills to boost their level of competence and confidence in choosing venture creation as a career path. Hence, the challenge is to empower students by providing learning opportunities facilitated by the educational process. Such an educational standard requires more commitment from institutions of higher learning, entrepreneurship educators and education policymakers. This leads to the first proposition in this paper:

Proposition 1: Students' intention to initiate a new venture enterprise in the future mostly depends on their level of entrepreneurial knowledge, skills and attitudes.

\section{Social Support and Entrepreneurial Intentions}

Social support is the perceived caring relationships that provide emotional reassurance, needed information or instrumental aid in dealing with stressful situations (Feeney and Collins, 2015). In line with Ajzen's theory of planned behavior, the perceived desirability of venture creation is influenced by social forces, primarily those forces of family and friends (Ajzen, 1991). Young potential entrepreneurs usually rely on their close networks, especially their family and friends for financial, human and social capital (Sieger \& Minola, 2017). The degree of family support may either empower or constrain potential entrepreneurs' intention of pursuing entrepreneurship as a career choice. This is more relevant in the Ghanaian context, where parents educate their children with the expectation of securing a 'good' job in the future (Ananga, Adzahlie-Mensah, \& Tamanja, 2016). A good job in this case, implies ensuring a white-collar job in an established organization with a lucrative salary and attractive working conditions. Similarly, Hartano (as cited in Sahban, Ramalu, \& Syahputra, 2016) reiterates that most parents of university graduates associate the prospects of being an entrepreneur with high risks. Such pessimistic beliefs could hinder and discourage young university graduates from starting their business ventures.

Key dimensions of social support relevant to entrepreneurial intention formation include 
emotional support, financial support and informational support (Farooq, 2018; Khan, 2016). Emotional support such as listening, empathy and encouragement (Edelman, Manolova, Shirokova \& Tsukanova, 2016) motivate potential entrepreneurs such as fresh graduates to act on their entrepreneurial intentions. Tangible support involves physical assistance such as providing financial support or advice aimed at helping the business starter to succeed (Lin, Hsu, Cheng, \& Chiu, 2015). Young graduates may be more likely to become entrepreneurs if they face fewer financial constraints. More so, parents offer valuable support to young graduates by supporting their entrepreneurial intentions. They can provide specific information or tacit knowledge on how to exploit opportunities and run a new business.

Entrepreneurs rely on family and friends and draw on a range of support from professional social networks and acquaintances for valuable information. In this case, information support provides relevant knowledge and advisory system necessary to guide inexperienced young potential entrepreneurs. These types of support can protect young graduates from uncertain and stressful situations. Information support makes it easier and 'cheaper' to do business. Therefore, we suggest a relationship between social support and entrepreneurial intention through the second proposition:

Proposition 2: The extent of social support and social networks can enhance students' perception and increase the probability of considering entrepreneurship as a good career choice.

\section{Business Opportunities and Entrepreneurial Intentions}

A university graduate can be tremendously creative, passionate and hard-working. Nonetheless, if a business opportunity is not perceived as desirable or feasible, intentions will not be implemented (Karimi, Biemans, Lans, Chizari \& Mulder, 2016). Likewise, entrepreneurial intention requires the convergence of two phenomena - lucrative opportunities and the presence of an entrepreneurial mindset. Recognizing gaps in the marketplace to create new or better products, services or processes can create lucrative opportunities.

Business opportunities are circumstances in which new products, services, resources and methods of operation can be introduced on the market to create greater value (Davidsson, 2015). Baron and
Hmieleski (2018) define business opportunities as "something new-a new product, a new way of making something, the discovery of or creation of a new market-that has not been and is not currently being exploited and that creates economic or social value. Besides, it is socially acceptable in the society in which it occurs" (p. 64). Thus, a business opportunity is an unmet consumer need or want that can potentially be met by a new business. Recognizing business opportunities is a skill that students can learn or sharpen.

Closely related to business opportunity is an idea, the cornerstone of an opportunity. However, not all ideas are valuable opportunities (Ma, Zhu, Meng, \& Teng, 2019; Bergmann, 2017). An idea is a condition that is necessary but not sufficient to be an opportunity. Opportunities may arise due to increased information available or by exploiting market inefficiencies resulting from information asymmetries and leading to access by only a small group of people (Nikraftar, \& Hosseini, 2016). Opportunities resulting from knowledge asymmetries emerge because each member of the society makes assumptions based on the information he/she may possess. On their basis, they make different assessments of the relative value involved in different resource uses and their potential for benefit (Venkataraman, 2019).

Therefore, entrepreneurial education should include entrepreneurial alertness to identify promising opportunities (Katz \& Green II, 2014). Tang, Kacmar, \& Busenitz (2012) proposed that alertness involves three basic dimensions: (1) alert scanning and search-searching the environment for opportunities; (2) alert association and connection-integrating various sources of information, to perceive links between them and use these as a basis for creating something new and valuable; and (3) evaluation and judgment-efforts to distinguish between opportunities offering low and high potential for creating value and choosing the most promising among them. Opportunities can be recognized, or they can be created by would-be entrepreneurs who imagine something that does not currently exist (Baron \& Hmieleski, 2018).

Business opportunities must meet the personal aspiration of the student and must be a viable business opportunity and a competitive edge. This opportunity must have the potential to fulfill the entrepreneur's ambitions and strengths to create novel ways to meeting market needs.

\section{East African Journal of Education and Social Sciences (EAJESS) 2(2)127-135}


From the work of Serzhanova (2016), the identification of opportunities consists of three distinct phases: (1) sensing or perceiving market needs and/or underused resources; (2) identifying or finding a match between market needs and resources; and (3) creating a new fit in the form of a business venture. A positive perception of a new business opportunity is defined as perceiving the potential new business opportunity to be both desirable and feasible (Karimi, Biemans, Lans, Chizari \& Mulder, 2016). A person who perceives a potential entrepreneurial opportunity positively perceives it as both viable and attractive. Understanding a possible entrepreneurial opportunity directly affects the decision of a person to proceed. Some scholars suggest that entrepreneurs seek opportunities other people do not see because they uniquely interpret these opportunities (Venkataraman, 2019). They tend to look more favorably at certain business situations and prospects than do non-entrepreneurs.

Opportunity identification is a cognitive task that enables people who are alert and keen to discover entrepreneurial opportunities (Salter, Ter Wal, Criscuolo, \& Alexy, 2015). According to the Global Entrepreneurship Monitor (2016), an average of $42 \%$ of working-age graduates see opportunities to start a company around them. However, only a few may take the requisite actions within a reasonable amount of time to initiate a business venture. Therefore, identifying opportunities and exploiting them are fundamental principles for successful entrepreneurial intentions. The relationship between entrepreneurial opportunity identification and entrepreneurial intent indicates that entrepreneurs need industry skills, expertise and knowledge (Miralles, Giones, \& Riverola, 2016). Given these observations, the authors argue that the existence of business opportunities and alertness of individuals to viable business opportunities would enhance the perceived desirability of establishing a venture. Hence, the third proposition:

Proposition 3: Perceived availability of viable business opportunities would lead to positive entrepreneurial intention and subsequent actions.

\section{Conclusion and Recommendations}

The need to explore entrepreneurial intentions among university students has never been more critical than it is today. Entrepreneurship is usually viewed as a key strategy for improving the employment rate and job creation necessary for economic development. Therefore, understanding the driving forces leading to entrepreneurial intentions among young graduates is critical for effective entrepreneurship education and subsequent self-employment. Equipping tertiary students with pertinent entrepreneurial competencies as well as providing social support and business opportunities can potentially enhance the entrepreneurial intentions of university students, particularly fresh graduates.

It is important to note that while most young university graduates may avoid pursuing entrepreneurship in favor of a 'safer' career choice, deliberately designed entrepreneurship education can create a positive perception of entrepreneurship, making it a possible and attractive career choice for fresh graduates. Unless students are supported, trained and equipped with valuable skills and competencies to recognize business opportunities, young graduates will have little confidence in their ability to run a business.

Therefore, fostering entrepreneurial intentions is not the work of only educators. Career counselors, parents, policymakers, and other professionals can equally support and influence young graduates to consider entrepreneurship a laudable career choice. Such a positive attitude may contribute to economic development and reduce unemployment.

The conceptual framework depicted in Figure 1 needs further empirical investigation with the anticipation of generating fresh research interest for future studies in entrepreneurial intentions among university graduates in Africa. Also, we acknowledge that other factors that may shape entrepreneurial intentions are not discussed in this conceptual paper.

\section{Reference}

Adelaja, A. A., \& Minai, M. S. (2018). Students Entrepreneurial Intention Changes Due to entrepreneurial education exposure: The experimental design approach. Journal of Entrepreneurship Education, 21(4), 1-12.

African Development Report (2016). Jobs for Youth in Africa: Catalyzing youth opportunity across Africa. https://www.afdb.org/fileadmin/uploads/af db/Images/high_5s/Job_youth_Africa_Job_ youth_Africa.pdf 
African Development Report (2017). Jobs for Youth in Africa Strategy. https://www.afdb.org/fileadmin/uploads/af $\mathrm{db} /$ Documents/Generic-

Documents/Ministerial_Conferences_Repor t_En.pdf

Ajzen, I. (1991). The theory of planned behavior. Organizational Behavior and human Decision Processes, 50 (2), 179-211.

Al Mamun, A., Nawi, N. B. C., \& Zainol, N. R. B. (2016). Entrepreneurial competencies and performance of informal micro-enterprises in Malaysia. Mediterranean Journal of Social Sciences, 7(3), 273.

Al-Jubari, I., Hassan, A. \& Liñán, F. (2019). Entrepreneurial intention among University students in Malaysia: Integrating selfdetermination theory and the theory of planned behavior. International Entrepreneurship and Management Journal, 15 , 1323-1342. https://doi.org/10.1007/s11365-018-0529-0

Amanamah, R. B., Acheampong, A., \& Owusu, E. K. (2018). An exploratory study of entrepreneurial intention among university students in Ghana. International Journal of Scientific \& Technology Research, 7(1), 140148.

Ananga, E.D., Adzahlie-Mensah, V. \& Tamanja, E. (2016). Higher education and employability in Ghana. In Universities, employability and inclusive development: Repositioning higher education in Ghana, Kenya, Nigeria and South Africa (pp. 77-90). British Council. https://ereadiness.kenet.or.ke/sites/default /files/ctools/Graduate\%20employability\%20 final\%20report.pdf

Aryeetey, E. (2001). Human Capital Development for Socioeconomic Transformation. Ghana in the 21st Century. ISSER Millennium Seminar Series, 8, Institute of Statistical, Social \& Economic Research, University of Ghana.

Baron, R.A. \& Hmieleski, K.M. (2018). Essentials of Entrepreneurship: Changing the world, one idea at a time (2nd ed.). Edward Elgar Publishing.

Bergmann, H. (2017). The formation of opportunity beliefs among university entrepreneurs: An empirical study of research-and non- research-driven venture ideas. The Journal of Technology Transfer, 42(1), 116-140.

Bosompem, M., Dadzie, S. K. N. \& Tandoh, E. (2017). Undergraduate students' willingness to start own agribusiness venture after graduation: A Ghanaian case. In P. Jones, G. Maas, \& L. Pittaway (Eds.), Entrepreneurship education: New perspectives on entrepreneurship education (pp. 75-106). Emerald Publishing Limited.

Ching, H. Y., \& Kitahara, J. R. (2017). Impact of the exposure to entrepreneurship education on students' entrepreneurial intentions: A casebased study of the higher education in Brazil. Business and Management Studies, 3(4), 85-93.

Dabic, M. and Pietrzykowski, M. (2011). Can entrepreneurship be brought from the $20^{\text {th }}$ to the $21^{\text {st }}$ century! A focus on Entrepreneurship Education through the FoSentHE 5e5 approach. In M. Dabic \& M. Pietrzykowski (Eds.), Fostering Education in Entrepreneurship (pp. 5-14). Bogucki Wydawnictwo Naukowe, Poland.

Davidsson, P. (2015). Entrepreneurial opportunities and the entrepreneurship nexus: A reconceptualization. Journal of Business Venturing, 30(5), 674-695.

De Wit, B. (2017). Strategy: An international perspective $\left(6^{\text {th }}\right.$ ed.). Cengage.

Denanyoh, R., Adjei, K., \& Danso, F. K. (2018). Graduate's perceptions of employment in micro small businesses in Ghana. International Journal of Business and Social Research, 8(9), 16-27.

Edelman, L. F., Manolova, T., Shirokova, G., \& Tsukanova, T. (2016). The impact of family support on young entrepreneurs' start-up activities. Journal of Business Venturing, 31(4), 428-448.

Esfandiar, K., Sharifi-Tehrani, M., Pratt, S., \& Altinay, L. (2019). Understanding entrepreneurial intentions: A developed integrated structural model approach. Journal of Business Research, 94, 172-182.

Farooq, M. S. (2018). Modelling the significance of social support and entrepreneurial skills for determining entrepreneurial behaviour of individuals: A structural equation modelling 
approach. World Journal of Entrepreneurship, Management and Sustainable Development, 14(3), 242-266.

Feeney, B. C., \& Collins, N. L. (2015). A new look at social support: A theoretical perspective on thriving through relationships. Personality and Social Psychology Review, 19(2), 113147.

Greene, F.J. (2020). Entrepreneurship: Theory and practice. Red Globe Press

Ham, M., Jeger, M. \& Ivković, A.F. (2015) The role of subjective norms in forming the intention to purchase green food. Economic ResearchEkonomska Istraživanja, 28(1), 738-748. https://doi.org/10.1080/1331677X.2015.10 83875

Jwara, N., \& Hoque, M. (2018). Entrepreneurial intentions among university students: A case study of Durban University of Technology. Academy of Entrepreneurship Journal, 24(3), 1-19.

Karimi, S., Biemans, H. J., Lans, T., Chizari, M., \& Mulder, M. (2016). The impact of entrepreneurship education: A study of Iranian students' entrepreneurial intentions and opportunity identification. Journal of Small Business Management, 54(1), 187209.

Katz, J. A. \& Green II, R.P. (2014). Entrepreneurial Small Business. McGraw-Hill Irwin.

Lackéus, M. (2015). Entrepreneurship in Education: What, Why, When, How. Entrepreneurship 360 Background Paper. LEED (Local Economic and Employment Development), OECD.

https://www.oecd.org/cfe/leed/BGP_Entre preneurship-in-Education.pdf

Lin, T. C., Hsu, J. S. C., Cheng, H. L., \& Chiu, C. M. (2015). Exploring the relationship between receiving and offering online social support: a dual social support model. Information \& Management, 52(3), 371-383.

Ma, Z., Zhu, J., Meng, Y., \& Teng, Y. (2019). The impact of overseas human capital and social ties on Chinese returnee entrepreneurs' venture performance. International Journal of Entrepreneurial Behavior \& Research, 25(1), 67-83.
Mamabolo, M. A., Kerrin, M., \& Kele, T. (2017). Entrepreneurship management skills requirements in an emerging economy: $A$ South African outlook. The Southern African Journal of Entrepreneurship and Small Business Management, 9(1), 1-10.

Markowska, M. (2011). Entrepreneurial competence development: Triggers, processes \& consequences [ JIBS Dissertation Series No. 071]. Jönköping University. http://www.diva-

portal.org/smash/get/diva2:458043/FULLTE XT02.pdf

Miralles, F., Giones, F., \& Riverola, C. (2016). Evaluating the impact of prior experience in entrepreneurial intention. International Entrepreneurship and Management Journal, 12(3), 791-813.

Morwitz, V. G. \& Munz, K.P (2021). Intentions. Consumer Psychology Review, 4 (1), 26-41.

Neck, H.M., Neck, C. P. \& Murray, E. L. (2021). Entrepreneurship: The practice and mindset (2nd ed.). Sage.

Nikraftar, T., \& Hosseini, E. (2016). Factors affecting entrepreneurial opportunities recognition in tourism small and medium sized enterprises. Tourism Review, 71(1), 6-17.

Ranga, V., Jain, S. \& Venkateswarlu, P. (2019). Exploration of Entrepreneurial Intentions of Management Students Using Shapero's Model. Theoretical Economics Letters, 9, 959-972. https://doi.org/10.4236/tel.2019.94062

Rebernik, M. \& Širec, K. Building entrepreneurship careers via entrepreneurship education. The case of Slovenia. In M. Dabic \& $M$. Pietrzykowski (Eds.), Fostering Education in Entrepreneurship (pp. 15-42). Bogucki Wydawnictwo Naukowe, Poland.

Robb, A. Valerio, A., \& Parton, B. (Eds). (2014). Entrepreneurship Education and Training: Insights from Ghana, Kenya, and Mozambique. World Bank Studies. World Bank. Doi:10.1596/978-1-4648-0278-2.

Sahban, M., Ramalu, S. S., \& Syahputra, R. (2016). The influence of social support on entrepreneurial inclination among business students in Indonesia. International 
Foundation for Research and Development (IFRD), 52.

Salter, A., Ter Wal, A. L., Criscuolo, P., \& Alexy, O. (2015). Open for ideation: Individual-level openness and idea generation in R\&D. Journal of Product Innovation Management, 32(4), 488-504.

Salunke, S., Weerawardena, J., \& McColl-Kennedy, J. R. (2019). The central role of knowledge integration capability in service innovationbased competitive strategy. Industrial Marketing Management, 76, 144-156.

Serzhanova, A. (2016). Assessing science based technological invention's commercialization opportunity through business modeling [Master's Thesis, University of Oulu]. http://jultika.oulu.fi/files/nbnfioulu201612013138.pdf

Shapero, A. (1982). Social dimensions of entrepreneurship. In C. A. Kent, D. L. Sexton, \& K. H. Vesper (Eds.) Encyclopedia of entrepreneurship (pp. 72-90). Prentice-Hall.

Sieger, P., \& Minola, T. (2017). The family's financial support as a "poisoned gift": A family embeddedness perspective on entrepreneurial intentions. Journal of Small Business Management, 55, 179-204.

Tang, J., Kacmar, K.M., \& Busenitz, L. (2012). Entrepreneurial alertness in the pursuit of new opportunities. Journal of Business Venturing, 27, 77-94.
Tognazzo, A., Gianecchini, M. \& Gubitta, P. (2017). Educational context and entrepreneurial intentions of university students: An Italian study. In P. Jones, G. Maas, \& L. Pittaway (Eds.), Entrepreneurship education: New perspectives on entrepreneurship education. Contemporary Issues in Entrepreneurship Research: Vol 7 (pp. 47 74). Emerald.

United Nations (n.d). Transforming our world: the 2030 Agenda for Sustainable Development. https://sdgs.un.org/2030agenda

Ustyuzhina, O, Mikhaylova, A, \& Abdimomynova, A. (2019). Entrepreneurial competencies in higher education. Journal of Entrepreneurship Education, 22(1), 1-14. https://www.abacademies.org/articles/Entr epreneurial-competencies-in-highereducation-1528-2651-22-1-292.pdf

Utami, C. W. (2017). Attitude, Subjective Norm, Perceived Behaviour, Entrepreneurship Education and Self Efficacy Toward Entrepreneurial Intention University Student in Indonesia. European Research Studies Journal, 20(2), 475-495.

Venkataraman, S. (2019). The distinctive domain of entrepreneurship research. In Seminal Ideas for the Next Twenty-Five Years of Advances (pp. 5-20). Emerald. 